\title{
An Open Letter to My Daughter
}

\author{
Rebecca L. Fisher*
}

\begin{abstract}
The author writes a poignant "open" letter to her daughter about her experience with breast cancer, the family legacy of breast cancer, and the impact of learning that there is a BRCAl mutation in the family.
\end{abstract}

Keywords: $B R C A 1$, breast cancer, genetic testing, family, coping

\section{Dearest Kate,}

The night you were born, huge brown eyes staring out of a tiny, pink, puzzled face, the nurses said you were the most beautiful baby in the nursery (they were right, of course!). You were already working your magic, making people fall in love with you. And your father and I fell first, first and hard.

We were so young, Kate; in love with each other and with you. Your dad had just turned 25 and I was $22-$ a year younger than you are now - a new college graduate with 18 months of marriage under my belt. But in a very real sense I was much older, made wise by years of believing that my time here on earth would not be long. I knew I needed to "get on with it" - to marry and have my babies young. My mother's, grandmother's, aunts', and cousins' breast and ovarian cancers had borne wretched witness to my darkest fears: something was killing us, maiming us, driving away our husbands and fathers, relegating the sickest among us to dimly lit hospital rooms where family members would gather and weep, gather and weep. I felt certain mine would be a truncated life; there was, I felt, little reason to believe otherwise.

You were only 9 years old when I finally did get sick, your brothers close behind at 6 and 4 . Smart as you were, I know you were a little confused when the five of us sat in our small living room for the talk about mommy's "bad lump," and even more confused when I came home from the hospital exhausted, sore

${ }^{*}$ Corresponding author: Rebecca L. Fisher, MS, 2104 Twin Mill Lane, Oakton, VA 22124, USA. Tel.: +1 7034037464 (cell); E-mail: RFisher284@aol.com. and bandaged in ways that kept me from hugging you. The pathology report told the story of just how bad the "bad lump" really was: only a half centimeter in size, it had already invaded 16 of 42 lymph nodes. Aggressive therapy - surgeries, drugs, radiation - was ahead ahead for all of us. I was 31 years old.

I know you have vague recollections of the long month I spent sequestered on the bone marrow unit at Jackson Memorial Hospital, your dad disappearing every evening - after feeding you and your brothers dinner and dropping you off at Gramma's house for the night to drive to my hospital room and sleep in the chair beside my bed. But there was one day you could not have known at the time was the very lowest point of my life. It was Mother's Day, 1993. They wheeled me down to a courtyard to spend a few minutes in the sunshine with you three while your dad videotaped our visit. From the vantage point of time, it is impossible not to see your discomfort: the boys' fidgeting and your nervous laughter were signatures of your shocked realization that the mommy who had gone away three weeks before was now someone entirely different. Skinny and bald, rash-covered, the mouth that had nuzzled your neck, read you bedtime stories, made up silly poems, and sung to you now hidden beneath a starchy, pleated facemask - all evidence that life was capricious and not to be trusted. The memory of that day remains an open wound all these years later. I think of those hours as the distillation of my cancer experience: full of alienation and despair, but also tethered to hope by love and outrage at the possibility of my children's growing up motherless. Love and outrage - an intoxicating cocktail my friends called "courage" - filled the glass through which I saw and I must admit, continue to see, 
the world. I wonder how that day shaped your Weltanschauung, your "look onto the world," but I suspect neither of us will know for many more years, when time and tears have eroded all that remains of our defenses.

What I do know is that the terrible foreshadowing of illness that characterized my own youthful but pessimistic worldview now has a name: BRCA1.

Technically the culprit isn't the $B R C A l$ gene itself but rather a mutation on it that, many scientists believe, keeps it from functioning as it should in the repair of DNA. The BRCA1 mutation, the first genetic tie to breast cancer, was discovered late in 1994. Suddenly we found ourselves circling wagons on the frontier of a new era in medicine: desperate for information, for guidance to help us forestall another cancer, another death, we finally received word about our family's specific mutation (an intervening sequence mutation between $\mathrm{A}$ and $\mathrm{T}$ on the $8^{\text {th }}$ intron) in 1997, only after both your aunts had had their breasts removed. Were you there the day I received the phone call from them, telling me they were actually negative for the mutation? News that was at once exhilarating (they didn't have it), devastating (their breasts were already gone), and stigmatizing (of the three of us, only I, it turned out, possessed it) shaped the day I discovered a new kind of sisterhood - with my mother.

And now with you. The night before we traveled to receive the results of your genetic testing, I scoured bookstores and the internet to find anything - anything written on how I should act, how we might feel, how we should consider the results of a possible "positive" result. I found nothing. So when the news was delivered like a rifle shot the next day in that small clinic room, the ricochet glanced off each of us - you, your $\mathrm{dad}$, me, the doctor, and the genetic counselor - before it came to rest in the silent, stunned realization that you, too, possessed the mutation that brought my cancer to me. Suddenly there was nothing in that room but you: no oxygen, no sound, no one else - not even myself. I was looking down on the scene, disassociated, images from my illness flooding in as I tried to gauge how you were feeling and what you thought. I glanced over at dad and saw a sense of resolve and acceptance that was reflected on your face. I thanked God for him - for the profoundly positive influence he has had in all our lives, for his love, and for his longsuffering, and for your inheriting his reason and calm, quickly realizing I was the most visibly disturbed person in the room.

It is the memory of illness, I now see, that makes this journey so difficult to undertake. It is the idea of seeing you suffer-all the possibilities: the loss of your breasts, the diagnosis of cancer, the chemotherapy, radiation, surgeries - even the idea makes me nauseated. I feel my spine turn to water and the sudden urge to sleep. . . when I awake, I think, I will have gleaned a few more grains of energy from the night to help me continue coping with the idea of your suffering. Then I think, "If this is what it feels like just to think about it, how will I ever be able to cope with the real thing?".

I know my mother asked the same question. Suddenly I want to know everything she felt after she heard the words, "Mom, I have a malignancy." I think of what she felt and thought after having been propelled forward, by the grace of God, through her own long, motherless childhood, her early cancer diagnosis, the loss of her home and her husband's abandonment, afterward. It is hard not to think of her as battered by the events of her life, but she would disavow any of that. She was too busy trying to survive, to raise her three daughters. She was too busy blazing the trail to indulge in much self-pity.

And that is what I will do for you: I will blaze the trail for you. Difficult decisions lie ahead: prophylactic surgeries or waiting to risk diagnosis of cancer, most likely. I will be here for you. I will show you how to survive. I will catch your tears in the font of my heart the way my mother did for me and her mother before her - and we will baptize the world with them.

I love you, Kate.

Love, Mom 